\title{
Effects of soil properties on phosphorus fractions in subtropical soils of Iran
}

\author{
E. Adhami ${ }^{1}$,H.R. Owliaie ${ }^{1}$, R. Molavi ${ }^{1}$, M. Rezaei Rashti ${ }^{2,3 *}$, M. Esfandbod ${ }^{2,3}$ \\ ${ }^{I}$ Soil Science Department, Yasouj University; Yasouj, Iran. ${ }^{2}$ Griffith School of Environment, Griffith University, Nathan, QLD., \\ 4111, Australia. ${ }^{3}$ Environmental Futures Centre, Griffith University, Nathan, QLD., 4111, Australia. Corresponding author: \\ m.rezaeirashti@griffith.edu.au
}

\begin{abstract}
The distribution of inorganic $\mathrm{P}$ fractions and their relationships with soil properties was studied in 17 slightly acidic to slightly alkaline soils ( $\mathrm{pH}$ range 5.37 to 7.61). The soils were selected from agricultural fields of the north of Iran. Inorganic $\mathrm{P}$ fractionation included successive extraction with $\mathrm{NaOH}$ (NaOH-P), citrate-bicarbonate (CB-P), citrate two times (C1- and C2-P), Citrate-ascorbate (CAs-P), citrate-dithionite-bicarbonate (CBD-P), sodium-acetate buffer (NaOAc-P) and $\mathrm{HCl}(\mathrm{HCl}-\mathrm{P})$. Results showed that the abundance of $\mathrm{P}$ fractions was in the order $\mathrm{NaOH}-\mathrm{P}$ (35.67 mg kg-1), NaOAc-P (39 mg kg-1), C2-P (49 mg kg-1), CBD-P (102 mg kg-1), CB-P (136 mg kg-1), CAs-P (156 mg kg $\left.{ }^{-1}\right)$, C1-P (197 $\left.\mathrm{mg} \mathrm{kg}^{-1}\right)$, HCl-P (417 mg kg-1). Among soil properties, $\mathrm{pH}$ had almost a linear negative relationship with $\mathrm{NaOH}-\mathrm{P}$ and a linear positive relationship with $\mathrm{HCl}-\mathrm{P}$; in addition, it significantly affected C1-P, CAs-P and NaOAc-P. Oxalate extractable Fe showed a significant positive correlation with $\mathrm{NaOH}-\mathrm{P}$ and CAs-P, while calcium carbonate equivalent (CCE) had a significant positive correlation with NaOAc-P and HCl-P.
\end{abstract}

Keywords: Inorganic phosphorus fractions, agricultural fields, $\mathrm{pH}$. 


\section{Introduction}

Phosphorus (P) fractionation is an applicable technique to determine the $\mathrm{P}$ status of soils and to study the chemistry and genesis of soils (Chang and Jackson, 1957; Cross and Schlesinger, 1995). Accurately characterizing $\mathrm{P}$ forms is a prerequisite to developing effective remediation strategies to minimize the adverse environmental impact of agricultural expansion. Knowledge of $\mathrm{P}$ fractions is important for evaluation its status in soil and understanding soil chemical properties that influence soil fertility and environmental quality. Soil P fractionation has been investigated since 1957 and was later applied to soils and sediments to overcome the limited information that total $\mathrm{P}$ analysis can provide (Zhou et al., 2001).

Principles of the fractionation methods are to displace $\mathrm{PO}^{4} \mathrm{P}$ from its sorption sites (through anion competition), to alter the adsorption surface, or to dissolve compounds containing P. The most easily desorbed and labile compounds are removed first with dilute reagents and the strength of the extractants increases stepwise, in order to separate more strongly bound $\mathrm{P}$ forms. Sequential chemical extraction methods have often been used to study the nature of $\mathrm{P}$ forms in soils and sediments. These methods are based on the selective extraction of operationally defined $\mathrm{P}$ fractions by using single extractants in a sequential manner (Hieltjes and Lijklema, 1980; Olsen and Sommers, 1982; Jiang and $\mathrm{Gu}, 1989$; Ruiz et al., 1997). In calcareous soils, $P$ is mainly bound to adsorption surfaces at low $(<10-4.5 \mathrm{M})$ concentrations of orthophosphate in solution (Borrero et al., 1988; Tunesi et al., 1999), whereas it is mainly precipitated as Ca phosphates at higher concentrations (Castro and Torrent, 1998; Tunesi et al., 1999). Soils that dominate humid temperate and tropical regions are highly weathered, acidic and dominated by large quantities of sesquioxides. These soils easily adsorb and geochemicaly fix phosphorus in many cases leading to phosphorus limitations (Cross and Schlesinger, 1995). In acid to neutral soils, Fe and Al phosphates are the typical precipitation products (Lindsay, 1979;
Pierzynski et al., 1990; Cross and Schlesinger, 1995). However, some heavily fertilized acidic soils contain significant amounts of Ca phosphates (Lookman et al., 1996), and hydroxyapatite has been found as a product of the dissolution of superphosphates in acidic and slightly acidic soils (Kumar et al., 1994). Pierzynski et al. (1990) showed that P-rich particles resulting from fertilizer dissolution in acid soils included not only $\mathrm{Al}$ and $\mathrm{Fe}$ but also $\mathrm{Si}$ and $\mathrm{Ca}$.

Soils of Guilan province, in the north of Iran, are characterized by acidic to neutral $\mathrm{pH}$, and more $\mathrm{Fe}$ and Al oxides than soils from other parts of the country (Ghasemi Fasaie et al., 2007). The climate is subtropical with an average rainfall of $1000 \mathrm{~mm}$ (Bahrami et al., 2010). Soil characteristics and suitability of the area for intensive crop production favor high application of inorganic $\mathrm{P}$ fertilizers annually, which has an important effect on the quality of surface water reservoirs (Sharpley and Tunney, 2000). Many studies has been conducted about $P$ chemistry and fractions in other parts of Iran (Khanmirzaie et al., 2009; Adhami et al; 2007 and 2006) while, such studies are rare in the north of Iran. The objectives of this study were to evaluate the status of $\mathrm{P}$ fractions in soils from agricultural fields of Guilan, in the north of Iran, and also investigate the relationships between soil properties and inorganic $\mathrm{P}$ fractions.

\section{Materials and methods}

Seventeen surface soil samples ( $0-0.30 \mathrm{~m}$ depth) with a wide range of physical and chemical characteristics from Guilan province in Iran were selected for this experiment. The soils were all from agricultural fields. One composite sample, consisted of at least 8 samples, of each soil was collected. The soil samples were air-dried and passed through a 2-mm sieve before analysis. Sand, silt and clay content were determined by hydrometer (Gee and Bauder, 1986). Cation exchange capacity (CEC; Sumner and Miller, 1996) by substitution of exchangeable cations with 
sodium acetate, calcium carbonate equivalent (CCE) by neutralizing with $\mathrm{HCl}$ (Loeppert and Suarez, 1996), organic matter content (Nelson and Sommers, 1996) by wet oxidation process, $\mathrm{pH}$ from a saturated paste (Thomas, 1996), and oxalate-extractable $\mathrm{Fe}\left(\mathrm{Fe}_{\mathrm{o}}\right.$; Loeppert and Inskeep, 1996) were determined (Table 1).

The inorganic $\mathrm{P}$ sequential fractionation scheme (Table 2) followed the Ruiz et al. (1997) sequence. Briefly, the procedure includes successive extraction with $\mathrm{NaOH}$ to remove soluble/exchangeable $\mathrm{P}$ and Al- and Fe-bound P; Na citrate bicarbonate (CB$\mathrm{P})$ to extract $\mathrm{P}$ readsorbed in the previous step and labile pedogenic $\mathrm{Ca}$-phosphates; $\mathrm{Na}$ citrate 2 times (C1 and $\mathrm{C} 2-\mathrm{P}$ ) reagents for extracting pedogenic $\mathrm{Ca}-$ $\mathrm{P}$; sodium-citrate ascorbate (CAs-P) for $\mathrm{P}$ occluded in poorly crystalline $\mathrm{Fe}$ oxides; citrate-dithionite bicarbonate (CBD-P) for $\mathrm{P}$ occluded in crystalline $\mathrm{Fe}$ oxides; $\mathrm{Na}$ acetate buffer for $\mathrm{Ca}-\mathrm{P}$ excluding lithogenic apatite; and $\mathrm{HCl}$ to remove mostly lithogenic apatite. All extractions were carried out on $1^{-\mathrm{g}}$ samples, in duplicate, with a ratio of 1: 40 soil: extractant. Following each step the samples were centrifuged at $6000 \mathrm{~g}$ for $15 \mathrm{~min}$ and the supernatant filtered through Whatman No. 42. Reactive P in the supernatant was determined using the ascorbic acid method at 882 nm (Murphy and Riley, 1962). Interference with citrate and dithionite was overcome by enrichment with ammonium molybdate (Ruiz et al., 1997) and ammonium persulfate, respectively.

\section{Results and discussion}

\subsection{NaOH-P}

The mean of NaOH-P was $35.67 \mathrm{mg} \mathrm{kg}^{-1}$ and it ranged from 13.2 to $72.61 \mathrm{mg} \mathrm{kg}^{-1}$ which accounted for $3.16 \%$ of the sum of the fractions. The amount and percentage of this fraction was obviously higher than those reported by Adhami et al. (2007) for 16 calcareous soils of the south of Iran. Most of the fractionation sequences for both calcareous and non-
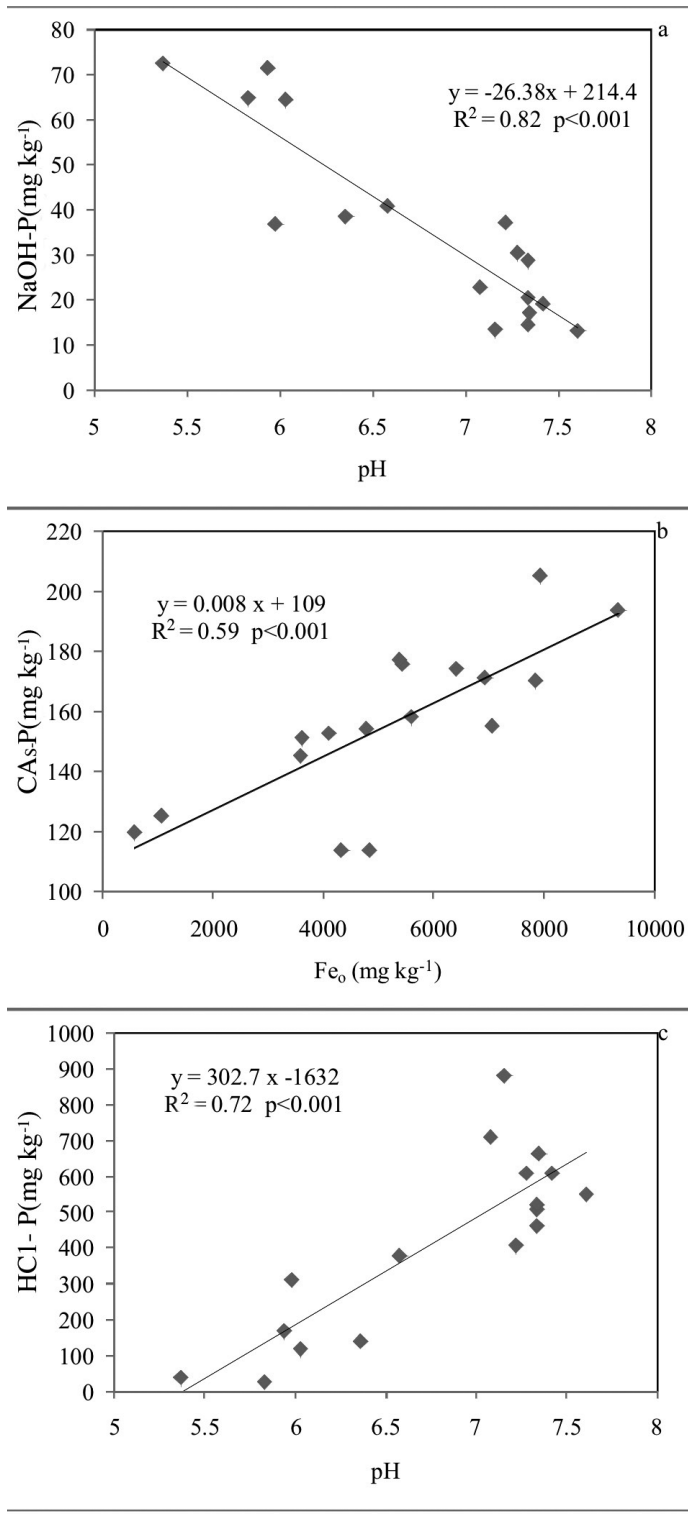

Figure 1. Relationships between a) $\mathrm{NaOH}-\mathrm{P}$ and $\mathrm{pH}$; b) citrate-ascobate extractable $\mathrm{P}$ (CAsP) and Oxalate extractable $\mathrm{Fe}\left(\mathrm{Fe}_{\mathrm{o}}\right)$; c) Relationship between HC1-P and $\mathrm{pH}$ 
calcareous soils starts with $\mathrm{NaOH}$ and attribute it to Fe- and Al-P (Chang and Jackson, 1975; Williams et al., 1971; Solis and Torrent, 1989; and Ruiz et al., 1997). This fraction constitutes a small fraction of $P$ in calcareous soils (Solis and Torrent, 1989; Adhami et al., 2007). Although Chang and Jackson (1957) observed that $\mathrm{NaOH}$ could dissolve $\mathrm{FePO}_{4} 2 \mathrm{H}_{2} \mathrm{O}$, its ability to extract $\mathrm{Fe}$ - and $\mathrm{Al}-\mathrm{P}$ in the presence of $\mathrm{CaCO}_{3}$ has been questioned (Williams et al., 1971). In the present study, $\mathrm{NaOH}-\mathrm{P}$ constituted a higher portion of inorganic $\mathrm{P}$ in more acidic soils $(6-11 \%$ of the sum of $\mathrm{P}$ fractions) than neutral to slightly basic soil (2-6 $\%$ of the sum of $\mathrm{P}$ fractions). The content of $\mathrm{NaOH}-\mathrm{P}$ was lower than those reported by Ruiz et al. (1997) in 10 neutral to acidic soil (28 to $\left.657 \mathrm{mg} \mathrm{kg}^{-1}\right)$. Ruiz et al. (1997) reported that in more acidic soils NaOH-P accounted for a substantial amount of the sum of inorganic P fractions.

Relationships between $\mathrm{NaOH}-\mathrm{P}$ and soil properties showed that it was negatively correlated with CCE and $\mathrm{pH}$; while it was positively correlated with $\mathrm{Fe}$ (Table 4). Among these properties, $\mathrm{pH}$ was the best variable to describe $\mathrm{NaOH}-\mathrm{P}$ variation (Figure 1a). Tyler (2002) studying 110 soils of northeast Sweden reported a close, almost linear, relationship between soil acidity and P-Fe. It was observed that P-Fe fraction constituted about $50 \%$ of inorganic $\mathrm{P}$ in most acid soils but less than $1 \%$ in moderately alkaline (calcareous) soils. Relationship between NaOH-P and soil properties is in agreement with the general assumption that $\mathrm{NaOH}$ extracts $\mathrm{Fe}$ - and Al-P.Since the decrease of soil $\mathrm{pH}$ is generally associated with the increase of Al- and Fe-oxides, the common expectation is the increase of $\mathrm{NaOH}-\mathrm{P}$ with decrease in soil $\mathrm{pH}$.

\subsection{Pedogenic $\mathrm{Ca}-\mathrm{P}$}

Citrate bicarbonate, and 2 consecutive citrate extractions used in the sequential fractionation scheme are proposed to remove pedogenic Ca-P (Ruiz et al., 1997; Delgado et al., 2000). Ranges for CB-P, C1-P and $\mathrm{C} 2-\mathrm{P}$, were $41.5-261 ; 144-359$ and $31-77 \mathrm{mg} \mathrm{kg}$ 1, respectively. Adhami et al. (2007) found that the average content of the sum of CB-, C1- and C2-P in 16 highly calcareous soils of the south of Iran was 238 , while in the present study it was $378 \mathrm{mg} \mathrm{kg}^{-1}$. The content of pedogenic Ca-P is also higher than those reported by Ruiz et al. (1997) in 10 slightly acidic soils. Climate of Guilan province is sub-tropical with an average rainfall of $1000 \mathrm{~mm}$ (Bahrami et al., 2010) which has resulted in soils with lower $\mathrm{pH}$, and more $\mathrm{Fe}$ and $\mathrm{Al}$ oxides than soils from other parts of the country. Thereupon, the general expectation was a lower content of pedogenic Ca-P such as CB-, C1and C2-P (Cross and Schlesinger, 1995); the opposite trend is probably caused by intensive application of inorganic $\mathrm{P}$ fertilizers in the region.

It is likely that metastable phases (i.e. dicalcium , octacalcium, and tricalcium phosphate) and possibly a small fraction of stable phase (hydroxyapatite) were dissolved in CB reagent (Delgado et al., 2000). Pedogenic Ca-P could be partly available to plants (Samadi, 2006; Khanmirzaie et al., 2009). Delgado et al. (2000) reported that part of Olsen P is originated from CB-P. On the other hand citrate is common reagent to evaluate $\mathrm{P}$ availability of fertilizers. The high content of pedogenic Ca-P in the studied soils indicates the high risks of adverse effects of $\mathrm{P}$ on both agricultural production and environmental quality.

In the present study CB-P and C-P (sum of C1and $\mathrm{C} 2-\mathrm{P}$ ) accounted for 12 and $21 \%$ of the sum $\mathrm{P}$ fractions; respectively. Saavedra and Delgado (2005) reported that the dominant $\mathrm{P}$ fractions in 17 soils from Spain were CB-P and C-P which were accounted for $31 \%$ and $30 \%$ of the sum of $\mathrm{P}$ fractions; respectively. Adhami et al. (2007) studying 16 calcareous soils of Iran observed that CB-P and C-P constituted $9.4 \%$ and $31 \%$ of the sum of $\mathrm{P}$ fractions.

Correlation of pedogenic $\mathrm{Ca}-\mathrm{P}(\mathrm{CB}, \mathrm{C} 1-$ and $\mathrm{C} 2-\mathrm{P})$ with soil properties showed no significant correlation except for C1-P with silt and $\mathrm{pH}$ (Table 4). Multiple regression analysis showed that $\mathrm{pH}$ and silt jointly could predict $51 \%$ of C1-P variation (Eq.1): 
Table 1. Some physico-chemical characteristics of the select soils.

\begin{tabular}{|c|c|c|c|c|c|c|c|c|c|}
\hline \multirow{2}{*}{$\begin{array}{l}\text { Soil } \\
\text { No. }\end{array}$} & \multirow[t]{2}{*}{ Altitudes } & Sand & Silt & Clay & $\mathrm{OC}^{\mathrm{a}}$ & $\mathrm{CCE}^{\mathrm{b}}$ & \multirow{2}{*}{$\begin{array}{c}\mathrm{Fe}_{\mathrm{o}}{ }^{\mathrm{c}} \\
\left(\mathrm{mg} \mathrm{kg}^{-1}\right)\end{array}$} & \multirow[t]{2}{*}{$\mathrm{pH}$} & \multirow{2}{*}{$\begin{array}{c}\mathrm{CEC}^{\mathrm{d}} \\
\left(\mathrm{cmol}_{\mathrm{c}} \mathrm{kg}^{-1}\right)\end{array}$} \\
\hline & & \multicolumn{5}{|c|}{$(\%)$} & & & \\
\hline 1 & $49^{\circ} 38^{\prime} 59^{\prime \prime}$ E, $37^{\circ} 11^{\prime} 56^{\prime \prime} \mathrm{N}$ & 6.0 & 59.0 & 35.0 & 2.63 & 1.9 & 5387 & 5.37 & 28 \\
\hline 2 & $50^{\circ} 10^{\prime} 02^{\prime \prime} \mathrm{E}, 37^{\circ} 10^{\prime} 01^{\prime \prime} \mathrm{N}$ & 54.0 & 25.5 & 20.5 & 1.76 & 2.9 & 5440 & 5.83 & 20 \\
\hline 3 & $49^{\circ} 13^{\prime} 50^{\prime \prime} \mathrm{E}, 37^{\circ} 31^{\prime} 26^{\prime \prime} \mathrm{N}$ & 21.0 & 41.0 & 38.0 & 5.67 & 8.0 & 9348 & 5.94 & 52 \\
\hline 4 & $49^{\circ} 53^{\prime} 41^{\prime \prime}$ E, $37^{\circ} 02^{\prime} 51^{\prime \prime} \mathrm{N}$ & 18.0 & 47.0 & 35.0 & 4.62 & 4.0 & 4785 & 5.98 & 43 \\
\hline 5 & $49^{\circ} 14^{\prime} 01 " \mathrm{E}, 37^{\circ} 19^{\prime} 38^{\prime \prime} \mathrm{N}$ & 16.0 & 56.0 & 28.0 & 2.46 & 2.4 & 6932 & 6.03 & 28 \\
\hline 6 & $49^{\circ} 28^{\prime} 48^{\prime \prime}$ E, $37^{\circ} 20^{\prime} 46^{\prime \prime} \mathrm{N}$ & 2.0 & 46.0 & 52.0 & 2.93 & 2.6 & 7921 & 6.36 & 36 \\
\hline 7 & $48^{\circ} 51^{\prime} 44^{\prime \prime}$ E, $38^{\circ} 20^{\prime} 11^{\prime \prime} \mathrm{N}$ & 8.0 & 52.0 & 40.0 & 1.98 & 5.1 & 7840 & 6.58 & 41 \\
\hline 8 & $49^{\circ} 42^{\prime} 02^{\prime \prime} \mathrm{E}, 37^{\circ} 15^{\prime} 40^{\prime \prime} \mathrm{N}$ & 31.3 & 40.7 & 28.0 & 3.03 & 3.4 & 4107 & 7.08 & 37 \\
\hline 9 & $48^{\circ} 54^{\prime} 26^{\prime \prime} \mathrm{E}, 37^{\circ} 58^{\prime} 02^{\prime \prime} \mathrm{N}$ & 26.0 & 38.0 & 36.0 & 2.29 & 7.8 & 5594 & 7.16 & 44 \\
\hline 10 & $50^{\circ} 15^{\prime} 43^{\prime \prime} \mathrm{E}, 37^{\circ} 06^{\prime} 21^{\prime \prime} \mathrm{N}$ & 24.0 & 48.0 & 28.0 & 2.80 & 6.3 & 6404 & 7.22 & 42 \\
\hline 11 & $49^{\circ} 25^{\prime} 45^{\prime \prime} \mathrm{E}, 36^{\circ} 49^{\prime} 06^{\prime \prime} \mathrm{N}$ & 42.0 & 41.0 & 17.0 & 3.20 & 12.2 & 1091 & 7.28 & 27 \\
\hline 12 & $49^{\circ} 49^{\prime} 16^{\prime \prime}$ E, $37^{\circ} 21^{\prime} 42^{\prime \prime} \mathrm{N}$ & 12.0 & 44.0 & 44.0 & 3.51 & 14.0 & 4335 & 7.34 & 45 \\
\hline 13 & $49^{\circ} 38^{\prime} 36^{\prime \prime} \mathrm{E}, 37^{\circ} 15^{\prime} 34^{\prime \prime} \mathrm{N}$ & 4.0 & 48.0 & 48.0 & 2.58 & 12.4 & 3610 & 7.34 & 43 \\
\hline 14 & $49^{\circ} 34^{\prime} 54^{\prime \prime}$ E, $36^{\circ} 59^{\prime} 55^{\prime \prime} \mathrm{N}$ & 31.0 & 48.0 & 21.0 & 1.65 & 11.8 & 4834 & 7.34 & 29 \\
\hline 15 & $49^{\circ} 57^{\prime} 15^{\prime \prime} \mathrm{E}, 37^{\circ} 17^{\prime} 36^{\prime \prime} \mathrm{N}$ & 63.7 & 28.5 & 7.8 & 0.89 & 9.9 & 582 & 7.35 & 14 \\
\hline 16 & $50^{\circ} 22^{\prime} 46^{\prime \prime}$ E, $37^{\circ} 05^{\prime} 12^{\prime \prime} \mathrm{N}$ & 32.0 & 48.0 & 20.0 & 4.07 & 16.5 & 7072 & 7.42 & 37 \\
\hline 17 & $49^{\circ} 30^{\prime} 09^{\prime \prime}$ E, $36^{\circ} 53^{\prime} 49^{\prime \prime} \mathrm{N}$ & 3.0 & 47.0 & 50.0 & 1.61 & 16.0 & 3593 & 7.61 & 38 \\
\hline
\end{tabular}

a, organic carbon; ;, calcium carbonate equivalent; ${ }^{\text {c, }}$ oxalate extractable Few; and d, cation exchange capacity. Current land uses of the soils are flooded rice; except for soil 11 which is under olive trees. 
$\mathrm{C} 1-\mathrm{P}=542-50.1 \mathrm{pH} \quad \mathrm{R}^{2}=0.33 \quad p<0.015$

$\mathrm{C} 1-\mathrm{P}=358-44.3 \mathrm{pH}+3.10$ silt $\quad \mathrm{R}^{2}=0.51 \quad p<0.007$

Adhami et al. (2007) observed a positive correlation between CB-P and silt fraction of the studied soils. Delgado and Torrent (2000) believe that C-P essentially correspond to sparingly pedogenic $\mathrm{Ca}$ P. Presumably, two consecutive citrate extractions, should extract mainly pedogenic Ca-P compounds. Delgado et al. (2000) explained that citrate in Ruiz's sequence essentially releases $\mathrm{P}$ related to $\mathrm{Ca}$-phosphate as a consequence of $\mathrm{Ca}$ complexation by citrate.

\subsection{Forms of Reductant $P$}

CAs-P ranged from w114 to $205 \mathrm{mg} \mathrm{kg}^{-1}$ (average $156 \mathrm{mg} \mathrm{kg}^{-1}$ ) and accounted for $14 \%$ of the sum of $\mathrm{P}$ fractions. Citrate ascorbate extractable $\mathrm{P}$ can be considered as mild reductant soluble $\mathrm{P}$, and is assumed to be $\mathrm{P}$ associated with poorly crystalline $\mathrm{Fe}$ oxides (e.g. ferrihydrate) (Ruiz et al., 1997, Delgado et al., 2000). The range of CBD-P was 36 to $262 \mathrm{mg}$ $\mathrm{kg}^{-1}$ with the average of $102 \mathrm{mg} \mathrm{kg}^{-1}$, and in average constituted 9 percent of the sum of $\mathrm{P}$ fractions. Citratebicarbonate-dithionite extractable $\mathrm{P}$ is part of soil-P which is released with the effect of a strong reductant (dithionite), generally is attributed to various forms of P occluded in crystalline Fe oxides (Ruiz et al.,1997). In most soils CAs-P was higher than CBD-P and in average CAs-P was 1.5 fold of CBD-P. This indicates that most of reductant soluble $\mathrm{P}$ in the studied soils is "mild reductant P". Ruiz et al. (1997) found that CAs-P ranged from 13 to $133 \mathrm{mg} \mathrm{kg}^{-1}$ in 12 soils of Europe and in most soils it accounted for more than $50 \%$ of reductant soluble P. Saavedra and Delgado (2005) reported that the average amount of CAs-P in 17 mediterranean soils was $11 \mathrm{mg} \mathrm{kg}^{-1}$. Although, the results of chemical $\mathrm{P}$ fractionation could not be directly used to $\mathrm{P}$ dynamics in natural environments, reductant soluble $\mathrm{P}$ (CAs-P and CBD-P) provides an index of $P$ that can be potentially released when soil material are subjected to reducing condition in natural environments. Thereupon, the high content of CAs-P in the studied soils indicates that most of the reductant soluble $P$ could be easily reduced and solubilized when subjected to reducing conditions, i.e. in waterlogged rice fields or sediments of water reservoirs.

In the present study, multiple regression analysis showed that $\mathrm{Fe}_{\mathrm{o}}$ could predict 59 percent of CAs-P variation (Figure 1b); while introducing $\mathrm{CCE}$ as the second variable increased $\mathrm{R}^{2}$ to 0.74 (Eq.3):

$\mathrm{CAs}-\mathrm{P}=136+0.007 \mathrm{Fe}_{\mathrm{o}}-2.205 \mathrm{CCER}^{2}=0.74 p<0.0001$

Although, citrate ascorbate is not a selective extractant for $\mathrm{P}$ associated with $\mathrm{Fe}$ oxides in highly calcareous soils (Ruiz et al., 1997; Adhami et al., 2007); the results of the present study shows that in acidic to slightly alkaline soils, citrate ascorbate mainly extracts $\mathrm{P}$ associated with $\mathrm{Fe}_{0}$. Relationship between CAs- $\mathrm{P}$ and $\mathrm{Fe}_{\mathrm{o}}$ is in accordance with the assumption that $\mathrm{CB}$ followed by 2 citrate extractions will remove all of the pedogenic $\mathrm{Ca}-\mathrm{P}$; therefore, the use of citrate ascorbate should increase the $\mathrm{P}$ release as a result of its reductant effect, and will not affect Ca-P (Ruiz et al., 1997; and Delgado et al., 2000).

\subsection{Lithogenic Ca-P}

NaOAc-P ranged from $7.26 \mathrm{mg} \mathrm{kg}^{-1}$ to $99.6 \mathrm{mg}$ $\mathrm{kg}^{-1}$; and in average consisted $4 \%$ of the sum of inorganic $\mathrm{P}$ fractions. In slightly acidic to neutral soils, NaOAc-P constituted 1 to $4 \%$ of the sum of $\mathrm{P}$ fractions while, in slightly alkaline soils it constituted 1 to $9 \%$ of the sum of $\mathrm{P}$ fractions. Sodium acetate buffer $\mathrm{pH} 4$ was introduced in fractionation schemes to extract $\mathrm{Ca}$ phosphate 
Table 2. Sequence of the used fractination scheme

\begin{tabular}{|c|c|c|c|c|c|}
\hline Step & Extractants & $\mathrm{pH}$ & $\begin{array}{l}\text { Shaking } \\
\text { time (h) }\end{array}$ & $P$ forms extracted & Abbreviation \\
\hline 1 & $0.1 \mathrm{M} \mathrm{NaOH} ; 1 \mathrm{M} \mathrm{NaCl}$ & - & 16 & $\mathrm{Al}$ - and Fe-bound $\mathrm{P}$ & $\mathrm{NaOH}-\mathrm{P}$ \\
\hline 2 & $0.27 \mathrm{M} \mathrm{Na}$ Cit.; $0.11 \mathrm{M} \mathrm{NaHCO}_{3}$ & $6-7$ & 16 & $\begin{array}{l}\text { P readsorbed in the previous step; } \\
\text { labile pedogenic } \mathrm{Ca} \text { - rich phosphates }\end{array}$ & CB-P \\
\hline 3 & $0.25 \mathrm{M} \mathrm{Na}$ Cit. & 6 & 16 & $\begin{array}{l}\text { Pedogenic Ca-P, much of the } \mathrm{NaOH} \\
\text { extractable P forms, if not dissolved }\end{array}$ & C1-P \\
\hline 4 & $0.20 \mathrm{M} \mathrm{Na}$ Cit. & $6-7$ & 8 & Same as the previous step & $\mathrm{C} 2-\mathrm{P}$ \\
\hline 5 & $0.2 \mathrm{M} \mathrm{Na}$ Cit.; $0.05 \mathrm{M}$ ascorbate & 6 & 16 & $\begin{array}{l}\text { P occluded in poorly crystalline } \mathrm{Fe} \\
\text { oxides }\end{array}$ & CAs-P \\
\hline 6 & $\begin{array}{l}0.27 \mathrm{M} \mathrm{Na} \text { Cit.; } 0.11 \mathrm{M} \mathrm{NaHCO}_{3} ; \\
0.12 \mathrm{M} \mathrm{Na} \text { dithionite }\end{array}$ & - & 16 & $\begin{array}{l}\text { Various forms of } \mathrm{P} \text { occluded in } \\
\text { crystalline Fe oxides }\end{array}$ & CBD-P \\
\hline 7 & $1 \mathrm{M} \mathrm{NaOAc}$ buffer & 4 & 6 & Ca-P excluding lithogenic apatite & NaOAc-P \\
\hline 8 & $1 \mathrm{M} \mathrm{HCl}$ & - & 16 & Mostly lithogenic apatite & HCl-P \\
\hline
\end{tabular}

excluding lithogenic Ca-P (Jiang and Gu, 1989; Ruttenberg, 1992; Barbanti et al., 2004; Ruiz et al., 1997). Adhami et al. (2007) observed that $\mathrm{NaOAc}-\mathrm{P}$ in 16 calcareous soils from south of Iran ranged from 8 to $76 \mathrm{mg} \mathrm{kg}^{-1}$ with an average of 36 $\mathrm{mg} \mathrm{kg}^{-1}$. Ruiz et al. (1997) reported that NaOAc-P ranged from 3 to $72 \mathrm{mg} \mathrm{kg}^{-1}$ in 12 noncalcareous and calcareous soils of Europe. Relationship between $\mathrm{NaOAc}-\mathrm{P}$ and soil properties showed a significant positive correlation with CCE, Clay and $\mathrm{pH}$ (Table 4). Multiple regression analysis showed that $70 \%$ of $\mathrm{NaOAc}-\mathrm{P}$ variation could be predicted by $\mathrm{CCE}$ and Clay (Eq.5):
$\mathrm{NaOAc}-\mathrm{P}=9.182+3.714 \mathrm{CCE} \quad \mathrm{R}^{2}=0.45 \quad p<0.004$

$\mathrm{NaOAc}-\mathrm{P}=-27.32+3.778 \mathrm{CCE}+1.116$ Clay $\mathrm{R}^{2}=0.70 p<0.001$

The relationships of NaOAc-P with $\mathrm{CCE}$ and clay are in accordance with the assumption that $\mathrm{NaOAc}$ in the Ruiz et al. (1997) sequence is capable of 
Table 3. Inorganic P fractions.

\begin{tabular}{|c|c|c|c|c|c|c|c|c|}
\hline \multirow{2}{*}{ Soil No. } & $\mathrm{NaOH}-\mathrm{P}$ & CB-P & C1-P & C2-P & CAs-P & CBD-P & $\mathrm{NaOAc}-\mathrm{P}$ & HCl-P \\
\hline & \multicolumn{7}{|c|}{$\left(\mathrm{mg} \mathrm{kg}^{-1}\right)$} & \\
\hline 1 & $72.6 \pm 4$ & $63.5 \pm 4$ & $280.7 \pm 6$ & $31.4 \pm 0$ & $177.2 \pm 7$ & $57.4 \pm 2$ & $10.0 \pm 1$ & $37.4 \pm 1$ \\
\hline 2 & $64.6 \pm 8$ & $118.4 \pm 5$ & $144.2 \pm 11$ & $37.9 \pm 3$ & $175.9 \pm 13$ & $66.5 \pm 4$ & $7.3 \pm 2$ & $27.2 \pm 1$ \\
\hline 3 & $71.3 \pm 7$ & $143.0 \pm 10$ & $229.7 \pm 15$ & $43.1 \pm 2$ & $193.7 \pm 2$ & $58.4 \pm 5$ & $32.7 \pm 2$ & $166.0 \pm 7$ \\
\hline 4 & 36. $9 \pm 1$ & $261.4 \pm 7$ & $252.4 \pm 10$ & $43.5 \pm 5$ & $154.2 \pm 5$ & $112.4 \pm 4$ & $40.3 \pm 2$ & $311.3 \pm 24$ \\
\hline 5 & $64.0 \pm 3$ & $105.3 \pm 5$ & $358.5 . \pm 12$ & $45.6 \pm 7$ & $171.2 \pm 10$ & $185.4 \pm 9$ & $18.7 \pm 1$ & $116.2 \pm 2$ \\
\hline 6 & $38.6 \pm 3$ & $141.0 \pm 9$ & $161.7 \pm 8$ & $39.1 \pm 1$ & $205.0 \pm 5$ & $262.4 \pm 2$ & $21.6 \pm 3$ & $139.6 \pm 7$ \\
\hline 7 & 40. $9 \pm 4$ & $180.3 \pm 5$ & $230.4 \pm 6$ & $55.1 \pm 4$ & $169.7 \pm 13$ & $100.8 \pm 0$ & $31.8 \pm 3$ & $377.3 \pm 10$ \\
\hline 8 & $22.7 \pm 0$ & $41.6 \pm 3$ & $163.9 \pm 10$ & $45.1 \pm 2$ & $152.6 \pm 12$ & $49.6 \pm 2$ & $19.4 \pm 8$ & $709.9 \pm 23$ \\
\hline 9 & $13.3 \pm 3$ & $89.9 \pm 8$ & $144.0 \pm 8$ & $38.7 \pm 2$ & $158.1 \pm 7$ & $63.3 \pm 5$ & $61.3 \pm 0$ & $880.3 \pm 31$ \\
\hline 10 & $37.1 \pm 2$ & $182.9 \pm 8$ & $182.2 \pm 12$ & $54.1 \pm 3$ & $174.2 \pm 12$ & $135.9 \pm 0$ & $26.6 \pm 1$ & 404. \pm 85 \\
\hline 11 & $30.3 \pm 3$ & $253.3 \pm 15$ & $267.4 \pm 15$ & $53.3 \pm 4$ & $125.2 \pm 4$ & $131.9 \pm 8$ & $19.4 \pm 1$ & $609 . \pm 329$ \\
\hline 12 & $20.6 \pm 2$ & $137.9 \pm 8$ & $153.6 \pm 6$ & $54.1 \pm 5$ & $113.7 \pm 3$ & $99.1 \pm 5$ & $99.6 \pm 3$ & $462.8 \pm 28$ \\
\hline 13 & $14.5 \pm 1$ & $134.0 \pm 3$ & $150.7 \pm 8$ & $31.2 \pm 5$ & $151.1 \pm 5$ & $69.7 \pm 2$ & $91.4 \pm 5$ & $508.8 \pm 12$ \\
\hline 14 & $28.7 \pm 0$ & $149.9 \pm 7$ & $144.0 \pm 6$ & $53.1 \pm 3$ & $113.7 \pm 5$ & $140.7 \pm 7$ & $20.4 \pm 0$ & $520.8 \pm 15$ \\
\hline 15 & $17.1 \pm 3$ & $122.3 \pm 6$ & $167.5 \pm 8$ & $34.2 \pm 2$ & $119.5 \pm 3$ & $36.3 \pm 3$ & $41.6 \pm 2$ & $662.1 \pm 20$ \\
\hline 16 & $19.2 \pm 0$ & $100.1 \pm 9$ & $157.9 \pm 5$ & $77.0 \pm 5$ & $155.5 \pm 5$ & $70.9 \pm 4$ & $47.0 \pm 5$ & $608.5 \pm 24$ \\
\hline 17 & $13.2 \pm 0$ & $93.4 \pm 5$ & $154.2 \pm 4$ & $32.9 \pm 2$ & $145.2 \pm 8$ & $88 \pm 1$ & $76.6 \pm 2$ & $550.4 \pm 15$ \\
\hline Average & 35.7 & 136 & 197 & 45.2 & 156 & 101.7 & 39.1 & 417.2 \\
\hline$\%$ of Sum & 3.2 & 12 & 17 & 4 & 13 & 9 & 3.6 & 37 \\
\hline
\end{tabular}

extracting Ca phosphate excluding lithogenic apatite. Content of $\mathrm{HCl}-\mathrm{P}$ ranged from 27 to $880 \mathrm{mg} \mathrm{kg}^{-1}$ with an average of $419 \mathrm{mg} \mathrm{kg}^{-1}$ and in average constituted $37 \%$ of the sum of P fractions. Adhami et al. (2007) reported that the average content of HCl-P in 16 calcareous soils of Iran was $125 \mathrm{mg} \mathrm{kg}^{-1}$. The content of HCl-P is also more than those observed by Ruiz et al. (1997) in 12 non-calcareous and calcareous soils of Europe (4 to $129 \mathrm{mg} \mathrm{kg}^{-1}$ ). Saavedra and Delgado (2005) found that the average content of HCl-P in 17 agricultural soils of SW Spain was 14 $\mathrm{mg} \mathrm{kg}{ }^{-1}$. It is believed that phosphorus extracted with a dilute acidic solution (e.g. $\mathrm{HCl} 0.25 \mathrm{M}$; or $\mathrm{H}_{2} \mathrm{SO}_{4} 0.25 \mathrm{M}$ ) is primary phosphorus minerals such as hydroxylor flourapatite (Chang and Jackson, 1957; Jiang and Gu, 1989; Adhami et al., 2007). Due to higher weathering, general expectation was the lower content of lithogenic Ca-P as the primary phosphorus minerals (Cross and Schesinger, 1995) in the region than the soils of sourh of Iran, the opposite trend is probably an effect of intensive application of inorganic $\mathrm{P}$ fertilizer. It has been reported heavily fertilized acid soils may contain significant amounts of Ca phosphates (Lookman et al., 1996), and hydroxyapatite has been found as a product of the dissolution of superphosphates in acid and slightly acidsoils (Kumar et al., 1994). The least content of HCl-P was belong to soil $2(\mathrm{pH}=5.83)$ 
Table 4. Corelation coefficient between inorgancic $P$ fractions and soil properties $(n=17)$

\begin{tabular}{lllllllll}
\hline $\begin{array}{l}\text { Soil } \\
\text { properties }\end{array}$ & NaOH-P & CB-P & C1-P & C2-P & CAs-P & CBD-P & NaOAC-P & HCl-P \\
\hline OM & $0.26^{\text {ns }}$ & $0.28^{\text {ns }}$ & $0.25^{\text {ns }}$ & $0.33^{\text {ns }}$ & $0.31^{\text {ns }}$ & $-0.01^{\text {ns }}$ & $0.04^{\text {ns }}$ & $-0.19^{\text {ns }}$ \\
Clay & $-0.043^{\text {ns }}$ & $-0.08^{\text {ns }}$ & $-0.10^{\text {ns }}$ & $-0.32^{\text {ns }}$ & $0.39^{\text {ns }}$ & $0.27^{\text {ns }}$ & $0.49^{*}$ & $-0.20^{\text {ns }}$ \\
Silt & $-0.19^{\text {ns }}$ & $0.00^{\text {ss }}$ & $0.51^{*}$ & $0.18^{\text {ns }}$ & $0.20^{\text {ns }}$ & $0.36^{\text {ns }}$ & $0.01^{\text {ns }}$ & $-0.26^{\text {ns }}$ \\
Sand & $-0.06^{\text {ns }}$ & $0.06^{\text {ns }}$ & $-0.18^{\text {ns }}$ & $0.14^{\text {ns }}$ & $-0.37^{\text {ns }}$ & $-0.36^{\text {ns }}$ & $-0.34^{\text {ns }}$ & $0.26^{\text {ns }}$ \\
CCE & $-0.66^{* *}$ & $0.06^{\text {ns }}$ & $-0.44^{\text {ns }}$ & $0.35^{\text {ns }}$ & $-0.63^{* *}$ & $-0.24^{\text {ns }}$ & $0.67^{* *}$ & $0.58^{*}$ \\
pH & $-0.90^{* *}$ & $0.00^{\text {ns }}$ & $-0.58^{*}$ & $0.31^{\text {ns }}$ & $-0.66^{* *}$ & $-0.11^{\text {ns }}$ & $0.56^{*}$ & $0.84^{* *}$ \\
$\mathrm{CEC}^{\text {ns }}$ & $-0.12^{\text {ns }}$ & $0.12^{\text {ns }}$ & $-0.10^{\text {ns }}$ & $0.18^{\text {ns }}$ & $0.27^{\text {ns }}$ & $0.02^{\text {ns }}$ & $0.48^{\text {ns }}$ & $0.11^{\text {ns }}$ \\
$\mathrm{Fe}_{\mathrm{o}}$ & $0.53^{*}$ & $-0.11^{\text {ns }}$ & $0.15^{\text {ns }}$ & $0.26^{\text {ns }}$ & $0.77^{* *}$ & $0.30^{\text {ns }}$ & $-0.23^{\text {ns }}$ & $-0.50^{*}$ \\
\hline
\end{tabular}

ns, not significant; * and $* *$ significant at $p<0.05$ and $p<0.01$; respectively.

\section{Conclusion}

The results reported herein showed that the abundance of inorganic P fractions in 16 slightly acidic to slightly alkaline soils of the north of Iran was in the order NaOH-P $\left(33 \mathrm{mg} \mathrm{kg}^{-1}\right)<\mathrm{NaOAc}-\mathrm{P}$ $\left(39 \mathrm{mg} \mathrm{kg}^{-1}\right)<$ C2-P $\left(49 \mathrm{mg} \mathrm{kg}^{-1}\right)<$ CBD-P $(102 \mathrm{mg}$ $\left.\mathrm{kg}^{-1}\right)<$ CB-P $\left(136 \mathrm{mg} \mathrm{kg}^{-1}\right)<$ CAs-P $\left(156 \mathrm{mg} \mathrm{kg}^{-1}\right)$ $<$ C1-P $\left(197 \mathrm{mg} \mathrm{kg}^{-1}\right)<$ HCl-P $\left(417 \mathrm{mg} \mathrm{kg}^{-1}\right)$. The studied soils showed a high inorganic $\mathrm{P}$ content, appeared almost in all of the $\mathrm{P}$ fractions, which is probably an effect of the intensive inorganic $P$ fertilizer application. Meanwhile the accumulation of pedogenic Ca-P (CB-P and C-P) shows the risk of adverse effect of $\mathrm{P}$ on environmental quality. The average content of reductant soluble P (Sum of CAs- and CBD-P) was $257 \mathrm{mg} \mathrm{kg}^{-1}$ of which $70 \%$ was belong to mild reductant $\mathrm{P}$ that might be easily solubilized under reducing conditions.

\section{References}

Adhami, E., Maftoun, M., Ronaghi, A., Karimian, N., Yasrebi, J., Assad , M.T. 2006. Inorganic phosphorus fractionation of highly calcareous soils. Commun. Soil Sci. Plant Anal. 37, 1877-1888.

Adhami, E., Memarian, H.R., Rassaei, F., Mahdavi, E., Maftoun, M., Ronaghi, A., Ghasemi- Fasaei, R. 2007. Relationship between phosphorus fractions and properties of highly calcareous soils. Aust. J. Soil Res. 45, 255-261.

Bahrami, A., Emadodin, I., Ranjbar Atashi, M., Bork, H.R. 2010. Land-use change and soil degradation: A case study, North of Iran. Agric. Biol. J. North Am. 1, 600-605.

Barbanti, A., Bergamini, M.C., Frascari, F., Miserocchi, S., Rosso ,G. 1994. Critical aspects of sedimentary phosphorus chemical fractionation. J. Environ. Qual. 23, 1093-1102. 
Borrero, C., Pena, F., Torrent J. 1988. Phosphate sorption by calcium carbonate in some soils of the Mediterranean part of Spain. Geoderma. 42, 261-269.

Castro, B.,Torrent, J. 1998. Phosphate sorption by calcareous Vertisols and Inceptisols as evaluated from extended P-sorption curves. Eur. J. Soil Sci. 49, 661-667.

Chang, S.C., Jackson, M.L. 1957. Fractionation of soil phosphorus. Soil Sci. 84, 133-144.

Cross, A.F., Schlessinger, W.H. 1995. A literature review and evaluation of the Hedley fractionation: Applications to the biogeochemical cycle of soil phosphorus in natural ecosystems. Geoderma. 64, 197-214.

Delgado, A., Torrent, J. 2000. Phosphorus forms and desorption patterns in heavily fertilized calcareous and limed acid soils. Soil Sci. Soc. Am. J. 64, 2031-2037.

Delgado, A., Ruiz, R.J., Campillo, M.C .del., Kassem, S., Andreu, L. 2000. Calcium- and iron-related phosphorus in calcareous and calcareous marsh soils: Sequential chemical fractionation and 31P nuclear magnetic resonance study. Commun. Soil Sci. Plant Anal. 31, 2483-2499.

Gee, G.W., Bauder, J.W. 1986. Particle-size analysis. In: Klute, A. (ed.) Methods of Soil Analysis. 2nd ed. Part 1. ASA, Madison, WI. pp. 383-411.

Ghasemi-Fasaei, R., Tavajjoh, M., Olama, V., Molazem, B., Maftoun, M., Ronaghi, A., Karimian, N., Adhami, E. 2007. Copper release characteristics in selected soils from southern and northern Iran. Aust. J. Soil Res. 45, 459-464.

Hieltjes, A., Lijklema L. 1980. Fractionation of inorganic phosphates in calcareous sediments. J. Environ. Qual. 9, 405-407.
Jiang, B., Gu, Y. 1989. A suggested fractionation scheme of inorganic phosphorus in calcareous soils. Fertilizer Res. 20, 159-165.

Khanmirzaei, A., Adhami, E., Kowsar, S.A., Sameni, A.M. 2009. Organic and Inorganic Forms of phosphorus in a calcareous soil planted to four species of Eucalyptus in southern Iran. Commun. Soil Sci. Plant Anal. 40, 3194-3210.

Kumar, V., Gilkes, R.J., Armitage, T.M., Bolland, M.D.A. 1994. Identification of residual P compounds in fertilized soils using density fractionation, X-ray diffraction, scanning and transmission electron microscopy. Fertilizer Res. 37, 133-149.

Lindsay, W.L. 1979. Chemical equilibria in soils. New York, John Wiley and Sons. pp. 162-205.

Loeppert, R.H., Suarez, D.L. 1996. Carbonate and gypsum. In: Sparks, D.L. (ed.) Methods of soil analysis. Part 3, 3rd ed. Madison, WI: SSSA, ASA. pp. 437-474.

Loeppert, R.L., Inskeep, W.P. 1996. Iron. In: Sparks, D.L. (ed.) Methods of soil analysis Part 3. 3rd ed. Madison, WI: SSSA, ASA. pp. 639-664.

Lookman, R., Geerts, H., Grobert, P., Merckx, R., Vlassak, K. 1996. Phosphate speciation in excessively fertilized soils: A $31 \mathrm{P}$ and $27 \mathrm{Al}$ MAS NMR spectroscopic study. Eur. J. Soil Sci. 47, 125-130.

Murphy, J., Riley, J.P. 1962. A modified single solution method for determination of phosphate in natural waters. Anal. Chim. Acta. 27, 31-36.

Muurman, R.P., Peech, M. 1968. Reaction products of applied phosphate in limed soils. Soil Sci. Soc. Am. Proc. 32, 493-496.

Nelson, D.W., Sommers, L.E. 1996. Total carbon, organic carbon and organic matter. In: Sparks, 
D.L. (ed.) Methods of soil analysis. Part 3. 3rd ed. Madison, WI: SSSA, ASA. pp. 961-1010.

Olsen, S.R., Sommers, L.E. 1982. Phosphorus. In Page, A.L. et al. (ed.) Methods of soil analysis. Part 2. 2nd ed. Agron. Monogr. No. 9. Madison, WI: ASA and SSSA. pp. 403-427.

Pierzynski, G.M., Logan, T.J., Traina, S.J., Bigham J.M. 1990. Phosphorus chemistry and mineralogy in excessively fertilized soils: quantitative analysis of phosphorus rich particles. Soil Sci. Soc. Am. J. 54, 1576-1583.

Ruiz, J.M., Delgado, A., Torrent, J. 1997. Iron-related phosphorus in overfertilized European soils. J. Environ. Qual. 26, 1548-1554.

Ruttenberg K.C. 1992. Development of a sequential extraction method for different forms of phosphorus in marine sediments. Limnol. Oceanogr. 37, 14601482.

Saavedra, C., Delgado, A. 2005. Iron-related phosphorus in eroded sediments from agricultural soils of Mediterranean areas. Geoderma. 125, 1-9.

Samadi, A.2006. Contribution of inorganic phosphorus fractions to plant nutrition in alkaline-calcareous soils. J. Agri. Sci. Technol. 8, 77-89.

Sharpley, A., Tunney, H. 2000. Phosphorus research strategies to meet agricultural and environmental challenges of 21st century. J. Environ. Qual. 29, 176-181.
Solis, P., Torrent, J. 1989. Phosphate fractions in calcareous Vertisols and Inceptisols of Spain. Soil Sci. Soc. Am. J. 53, 462-466.

Sumner, M.E., Miller, W.P. 1996. Cation exchange capacity and exchange coefficients. In: Sparks, D.L. (ed.) Methods of soil analysis. Part 3. 3rd ed. Madison, WI: SSSA, ASA. pp. 1201-1229.

Thomas, G.W.1996. Soil pH and soil acidity. In: Sparks, D.L. (ed.) Methods of soil analysis. Part 3. 3rd ed. Madison, WI: SSSA, ASA. pp. 475-490.

Tunesi, S., Poggi, V., Gessa, C. 1999. Phosphate adsorption and precipitation in calcareous soils: the role of calcium ions in solution and carbonate minerals. Nutr. Cycl. Agroecosys. 53, 219-227.

Tyler, G. 2002. Phosphorus fractions in grassland soils. Chemosphere. 48, 343-349.

Williams, J.D.H., Syers, J.K., Harris, R.F., Armstrong D.E. 1971. Fractionation of inorganic phosphate in calcareous lake sediments. Soil Sci. Soc. Am. Proc. 35, 250-255.

Zhou, Q., Gibson, C.E., Zhu Y. 2001. Evaluation of phosphorus bioavailability in sediments of three contrasting lakes in China and the UK. Chemosphere. 42, 221-225. 